\title{
GENE FREQUENCIES IN WILD POPULATIONS OF TRIFOLIUM REPENS L.
}

\author{
III. WORLD DISTRIBUTION \\ HUNOR DADAY \\ Division of Plant Industry, C.S.I.R.O., Canberra, Australia
}

\section{INTRODUCTION}

Received 26.vi.57

Although there have been a great number of publications describing morphological and cytological adaptation, Dobzhansky (I95I) has stated that " the extent of the diversity of physiological and biochemical traits in living beings is still quite imperfectly known ". The aim of this investigation was to establish the pattern of gene controlled chemical variation in world populations of Trifolium repens.

It is already known that $T$. repens possesses cyanogenetic glucosides consisting of 80 per cent. lotaustralin and 20 per cent. linamarin (Melville and Doak, I 940) and their hydrolysing enzyme linamarase (Coop, 1940). One of the products of hydrolysis is HCN. This was believed to cause bloat or poisoning effects in ruminants but Corkill (I952) was unable to demonstrate deleterious effects when sheep were grazed on high cyanogenetic glucoside lines of $T$. repens.

The presence of these cyanogenetic glucosides and their hydrolysing enzyme in $T$. repens is determined by independent single genes (Corkill, I942 ; Atwood and Sullivan, I943) while modifying genes determine the quantity of cyanogenetic glucosides produced (Corkill, I942). In the following pages the term "lotaustralin" is used instead of cyanogenetic glucosides and "linamarase" refers to the hydrolysing enzyme. Previous investigations (Daday, 1954a) demonstrated that the frequencies of the lotaustralin and linamarase genes varied from o to roo per cent. in European and Near Eastern wild populations of $T$. repens. A similar gene frequency cline was observed in Alpine populations (Daday, $1954 b$ ). Winter temperature was considered to be the major factor responsible for the formation of these gene frequency clines in wild populations.

The major part of this investigation was carried out at the Welsh Plant Breeding Station, Aberystwyth, Great Britain and completed at C.S.I.R.O., Canberra.

\section{METHODS}

The presence of lotaustralin and linamarase in plants was shown by the Guinard picric acid paper test (Corkill, 1940) with certain modifications (Daday, 1954a). According to their chemical constituents the plants were classified into four chemical phenotypes: (I) Lotaustralin and linamarase $(A c L i)$; (2) Lotaustralin only (Acli); (3) Linamarase only $(a c L i)$; (4) Neither lotaustralin nor linamarase (acli). (Appendix I).

The gene frequencies were calculated by the Hardy-Weinberg formula. 
The collection of seed samples was organised by the British Council, the United States Department of Agriculture, and Universities and Agricultural Experiment Stations of various countries. The technique of collection has been described in a previous paper (Daday, 1954a).

\section{GEOGRAPHICAL DISTRIBUTION OF T. REPENS}

$\tau$. repens is a typical species of the temperate regions of the world. However, the high adaptability of the species enabled it to extend to the Arctic regions (Murmansk, Kanin Peninsula, U.S.S.R.) and to the sub-tropical regions as in Queensland (Australia). The geographical distribution of $T$. repens is presented in fig. $I$.

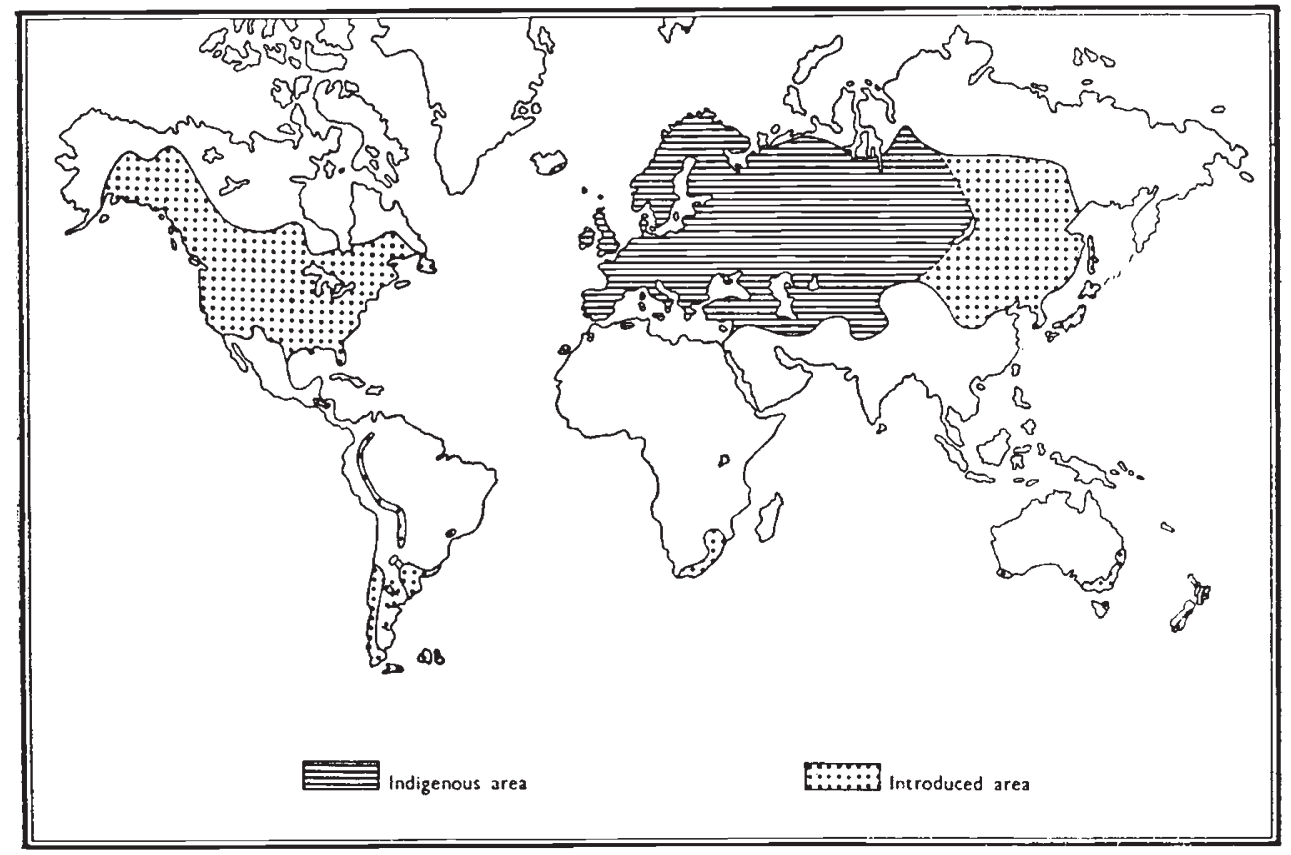

FIG. I.-Geographical distribution of Trifolium repens L.

The Mediterranean region is considered by Vavilov (I95I) to be the centre of origin of $T$. repens. This species has spread all over Europe and has also invaded the larger part of Asia by means of animal, human and spontaneous distribution. Its occurrence is recorded on the Asiatic mainland (Komarovii, I945) as follows : Turkey, Lebanon, Israel, Iraq, Persia, Pakistan, India (Himalaya Range up to 20,00o feet), U.S.S.R., China, Mongolia and Korea. It is considered that the indigenous area consists of the whole European and the western half of the Asiatic distribution area, whilst east from the Baikal Lake is the recently occupied region. Personal information obtained from Japan indicates that the first sample of $T$. repens was carried by a Dutch vessel which arrived at Nagasaki in I846. This is considered as one of the ancestral sources of the Japanese $T$. repens.

This species is indigenous to North Africa. It occurs both in low 
land and at high elevations (Atlas Mountains) in Morocco and Tunisia wherever sufficient soil moisture is available. One collection came from an altitude of 7500 feet. The plant was introduced into South Africa, establishing itself in Cape Province and in cool mountain areas where the rainfall is evenly distributed and along stream banks in Natal, Transvaal, and Pretoria. Botanical surveys indicate the presence of the species in natural vegetation on the Canary Islands.

T. repens was introduced into North America by the earliest settlers and now it is extremely abundant in most of the settled areas. It is one of the most widespread species and extends northward to Canada and Alaska. It has invaded the whole U.S.A. but between the Cascade, Sierra Nevada mountains and the $100^{\circ}$ parallel, grows along rivers, around habitations and irrigated fields. According to a personal communication, T. repens was carried to Alaska in about 1920.

The distribution of introduced $T$. repens is restricted to the temperate regions in Central and South America. It occurs in the high altitudes of the Andes and other mountainous regions in Guatemala, Costa Rica, Venezuela (up to gooo feet), Columbia, Peru, and Bolivia. Comparatively recent introduction started the spread of this species in Brazil (Rio Grande do Sul, Minas Gerais). It is more common in Chile, and in the humid parts of Argentina and some fertile regions of Uruguay.

T. repens is not indigenous in Australia and New Zealand. The spontaneous spread of this species is mainly restricted to humid coastal regions of Australia, but is often seen along streams, and under irrigation in the drier areas. This species was introduced as a pasture plant during the early history of New Zealand and was used to oversow cleared forest areas, bush burns, and tussock grassland areas. Now it has become the most important legume component of the grassland vegetation but it also appears naturally along roadsides and where the soil has been disturbed.

\section{GENE FREQUENCIES IN WILD POPULATIONS OF THE WORLD}

A survey of lotaustralin and linamarase gene frequencies (Daday, 1954a) in European and Near Eastern T. repens populations disclosed a cline of dominant gene frequency from the warm winter region, where high frequencies predominate, to low frequencies which are most common in Northern Europe. This species is considered to have spread by natural means to the largest part of the Asiatic distribution area.

Four samples were tested (Appendix I) from the mainland of Asia. The southern populations exhibited a higher frequency (Iran, Karaj river area, $A c$ 100.0, Li $40 \cdot 6$ per cent.; India, Almora, $A c$ $67 \cdot 1, \mathrm{Li} 73 \cdot 2$ ) than those collections derived from U.S.S.R. (Turgatuj

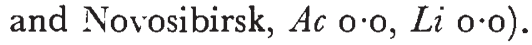


Seven samples represent the Japanese T. repens populations. Four of these originated from the southern warm winter regions and three from the cold winter regions. The warm winter region collections are from the South Pacific Coast Region (Miyazaki and Kochi), Seto-Inland-Sea Coast Region (Zentsuji) and the Kanito region with a dry winter climate (Konosu collection). They represent rather mixed gene frequencies ( $A c \mathrm{I}_{4} \cdot 7 \cdot 52 \cdot 3, \mathrm{Li}$ i $8 \cdot 8-42 \cdot 3$ per cent.). The remaining three samples are from the Sea Coast Region in a cool winter area of Japan, Shindo-Mura ( $A c 54^{\cdot} 7, \operatorname{Li} 2$ I.5 per cent.) ; the cold area of the Pacific Coast Tohoku (North Eastern) Region represented by the Shimo-Kuriyagawa collection (Ac $26 \cdot 6 ; \mathrm{Li} 28 \cdot 0$ per cent.) ; and the coldest winter region of Japan, Hokkaido in the north, where $A c$ I $5^{\circ} \mathrm{O}, \mathrm{Li} 23^{\circ} 2$ exhibit the lowest frequencies in the Tsukissapau sample. The Japanese samples may thus be divided into those from the southern warm winter region with mixed gene frequencies, and those from the northern colder winter area with decreasing gene frequencies of $A c$.

T. repens is indigenous to North Africa, where it shows some indication of altitudinal gene frequency clines (Rabat, near sea level, $A c$ гоo.o, $L i$ гоo.o; Tirsal, at 4500 feet, $A c$ гоo.0, $L i$ гоo.o; Oukaiemden, at 7500 feet, $A c 59.7$ and $L i 69.5$ per cent.). All the samples tested from South Africa varied between $5 \mathrm{I} \cdot 7$ and $9 \mathrm{I} \cdot \mathrm{O}$ per cent. for $A c$, and $43^{\circ} \mathrm{O}$ and $70^{\cdot 2}$ per cent. for $L i$. There is no evidence for gene frequency cline formation in South Africa.

The U.S.A. and Canadian populations are represented by considerable numbers of $T$. repens samples from Louisiana to Alaska. A high mean lotaustralin gene frequency was found in most of the samples above the $40^{\circ} \mathrm{F}$. January isotherm (Baton Rouge $7 \mathrm{r} \cdot 9$, New Orleans 75.8, San Francisco 6r ${ }^{4}$, San Francisco 84.3, Rio Monte I 00.0 for $A c$ gene frequencies). Between the $40^{\circ}$ and $0^{\circ} \mathrm{F}$. isotherm, there are collections from Oregon, Ohio, Nebraska, Illinois, Minnesota, Alaska, Quebec and Alberta which exhibit rather mixed gene frequencies with respect to the $A c$ gene. However, $32 \cdot 6$ to $2 \cdot 2$ per cent. frequencies were found below the $0^{\circ} \mathrm{F}$. line (Brandon, Fairbanks). This relationship between the January mean temperature of localities and gene frequencies (fig. 2) is highly significant $(\mathrm{P}<0.00 \mathrm{r})$.

The regression slope indicates that the change in the $A c$ frequency is $0.68 \mathrm{I}$ per cent. per $\mathrm{I}^{\circ} \mathrm{F}$. mean temperature. The relationship between $L i$ gene frequencies and temperature change is not significant. Natural selection seems to have occurred in North America and a frequency cline for the $A c$ gene has already formed. The occurrence of a $L i$ frequency cline in North America does not seem to have any statistical support.

South American collections were obtained from Peru, Brazil and Argentina. Gene frequencies vary considerably, 7.9-100.0 per cent. for the $A c$ gene and I $3^{\cdot 0-100 \cdot 0}$ per cent. for the $L i$ gene. The lowest Ac frequency ( 7.9 per cent.) was found at Pedro Leopoldo in Minas 
Gerais, Brazil, where the winter temperature is characterised by being the highest $\left(60^{\circ} \mathrm{F}\right.$.) among the sampled areas. High $A c$ frequencies were established at Esquel, Argentina, where the mean temperature is the lowest among the samples $\left(30^{\circ} \mathrm{F}\right.$.). The mean July temperatures of these South American localities are comparatively high $\left(30-60^{\circ} \mathrm{F}\right.$.) and no collection was obtained from regions having July mean temperatures below $30^{\circ} \mathrm{F}$. The absence of a gene frequency cline might reflect the absence of a large range in winter temperature in the parts of South America studied.

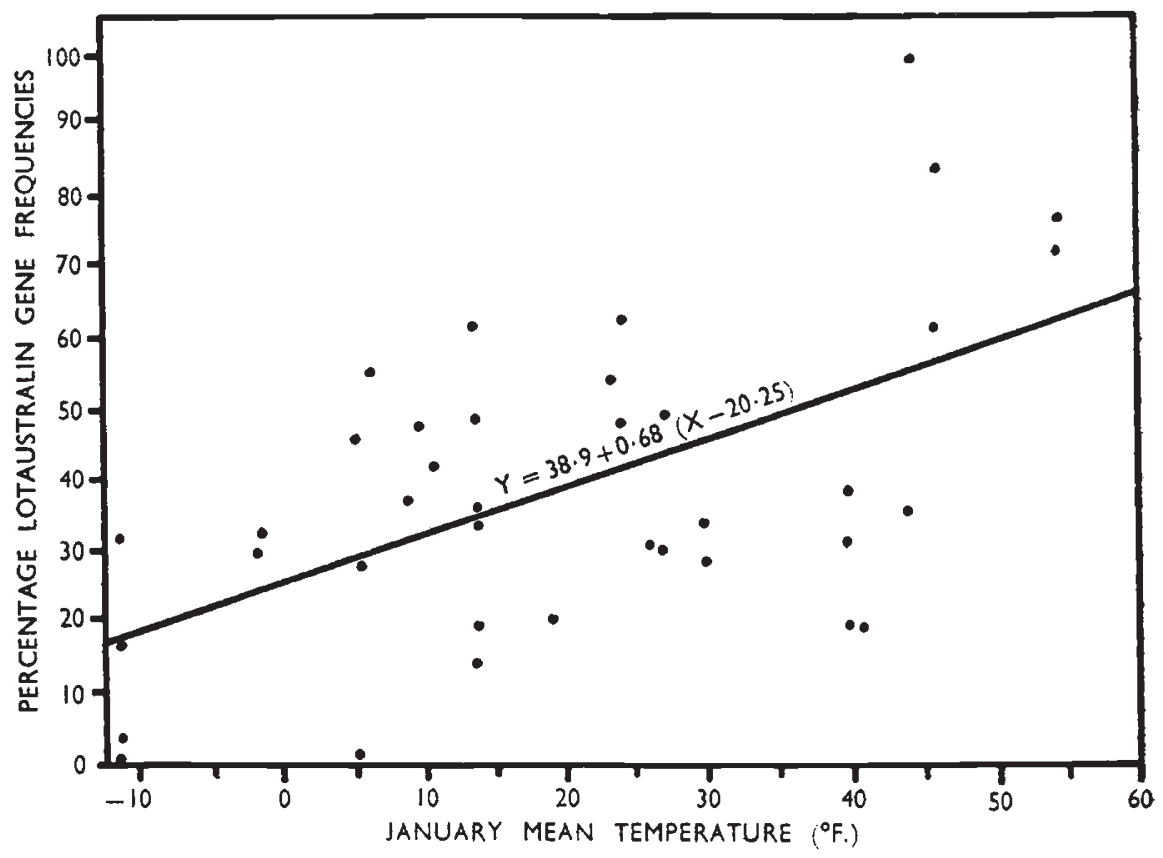

Fig. 2.- Ciorrelation between lotaustralin gene $(A c)$ frequencies and January mean temperature in North American wild populations of T. repens.

Australian populations were represented by collections from old established pastures of New South Wales, Victoria, Tasmania, South Australia, and the Australian Capital Territory. Apart from the low land collections, altitudinal samples (Mt. Kosciusko, Mt. Gingera) were also tested. The frequencies of $A c$ range from $0 \cdot 0$ to $75^{\circ} \mathrm{I}$ per cent. and those of $L i$ from $6 \cdot$ I to $78 \cdot 8$ per cent. in low land populations. There was no pattern or indication of cline formation. Mt. Kosciusko is in New South Wales and has the coldest winter in Australia. The highest elevations are covered by snow for 6 to 8 months of the year. Collections were made at altitudes from 3000 to 5800 feet. $A c$ frequencies were uniformly low $(3.2$ to 8.2 per cent.) but variable proportions of $L i$ frequencies $\left(28 \cdot 6\right.$ to $5^{\mathrm{I}} \cdot 2$ per cent.) were found in this region. 
The North and South Islands of New Zealand were represented by four collections. Hastings exhibited roo $\cdot 0$ per cent. frequency for the $A c$ gene ( $L i 88 \cdot 0$ ), while the lowest frequency, 37.7 per cent. for $A c$ ( $L i 70 \cdot 0$ per cent.), was at Winston. Other $A c$ values varied between these extremes.

The samples collected in Japan, South Africa, South America, Australia and New Zealand appear to be rather heterogeneous. The $\chi^{2}$ test for heterogeneity has been carried out for samples of each of the above geographical areas. The heterogeneity test proved to be highly significant for all the samples with the exception of $L i$ containing plants in New Zealand.

The geographical distribution of the lotaustralin gene frequencies in $T$. repens populations of the world is illustrated in fig. 3. Both Europe and the mainland of Asia show a roo-o per cent. decrease. This gradual diminishing in gene frequencies occurs across the January isotherms. Above the $50^{\circ} \mathrm{F}$. isotherm all populations have $100 \cdot 0$ per cent. dominant $A c$ frequency. Below the $50^{\circ} \mathrm{F}$. isotherm the gene frequencies fall from I00 0 to 5.0 per cent. at the $30^{\circ} \mathrm{F}$. isotherm. The rest of the area has 5 per cent. or lower frequencies. In North America, $100^{\circ} 0$ to $60^{\circ} 0$ per cent. was the most common frequency above the $40^{\circ} \mathrm{F}$. isotherm, whilst below the $0^{\circ} \mathrm{F}$. isotherm, dominant gene frequencies below $30 \cdot 0$ per cent. prevailed. $A c$ gene frequencies in northern Japanese populations also show a tendency to diminish with decreasing winter temperature. With the exception of mountainous regions with cool winters, mixed gene frequencies have been found all over the southern hemisphere.

Linamarase gene frequencies are presented in fig. 4. As with $A c$, the $L i$ frequency variation occurred within a range of roo per cent. in Europe and Asia. More variable than $A c$, but still high, were the frequencies of $L i$ above $50^{\circ} \mathrm{F}$. The decrease at lower temperatures was not as sharp as with the $A c$ gene. The mean frequency of $L i$ is 15 per cent. at the $30^{\circ} \mathrm{F}$. isotherm and then it gradually falls to o per cent. No cline has yet been found in recently colonised areas of the northern hemisphere. Mixed populations have also been found in the southern hemisphere.

The quantity of lotaustralin and linamarase produced by plants varies considerably. Corkill (1942) showed that modifying genes determined the amount of lotaustralin synthesised by plants. The relationship between the $A c$ gene frequencies and the mean rating of lotaustralin produced by world $T$. repens populations is presented in fig. 5 .

Association between $A c$ frequencies and mean rating was examined by classifying the data into a $3 \times 3$ contingency table with the boundaries defined by dividing the range of each variable into thirds. $\chi^{2}$ is $40^{\circ} 4 \mathrm{I}$ with $4 \mathrm{df}(\mathrm{P}<0.00 \mathrm{I})$ so that an association clearly exists. 


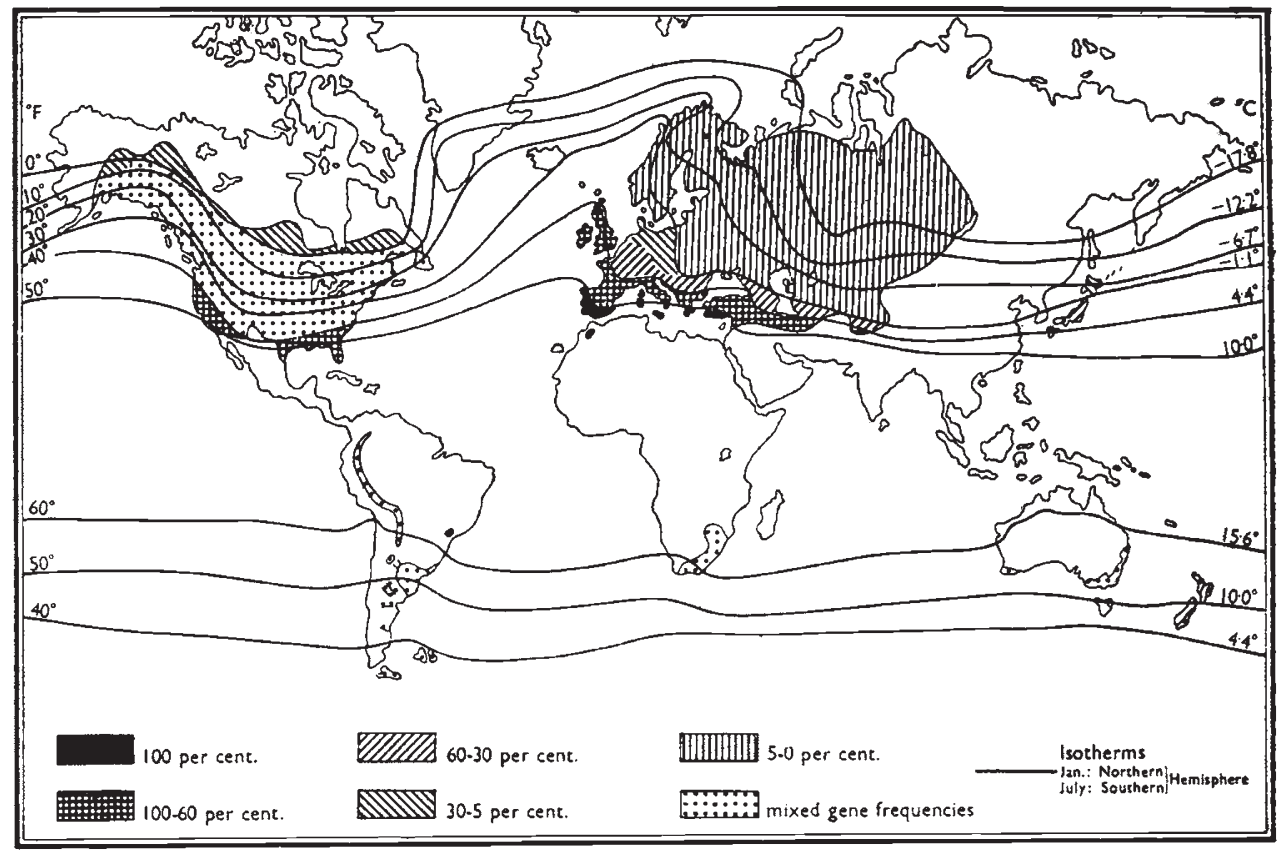

FIG. 3.-Distribution of lotaustralin gene frequencies in world populations of Trifolium repens $\mathrm{L}$.

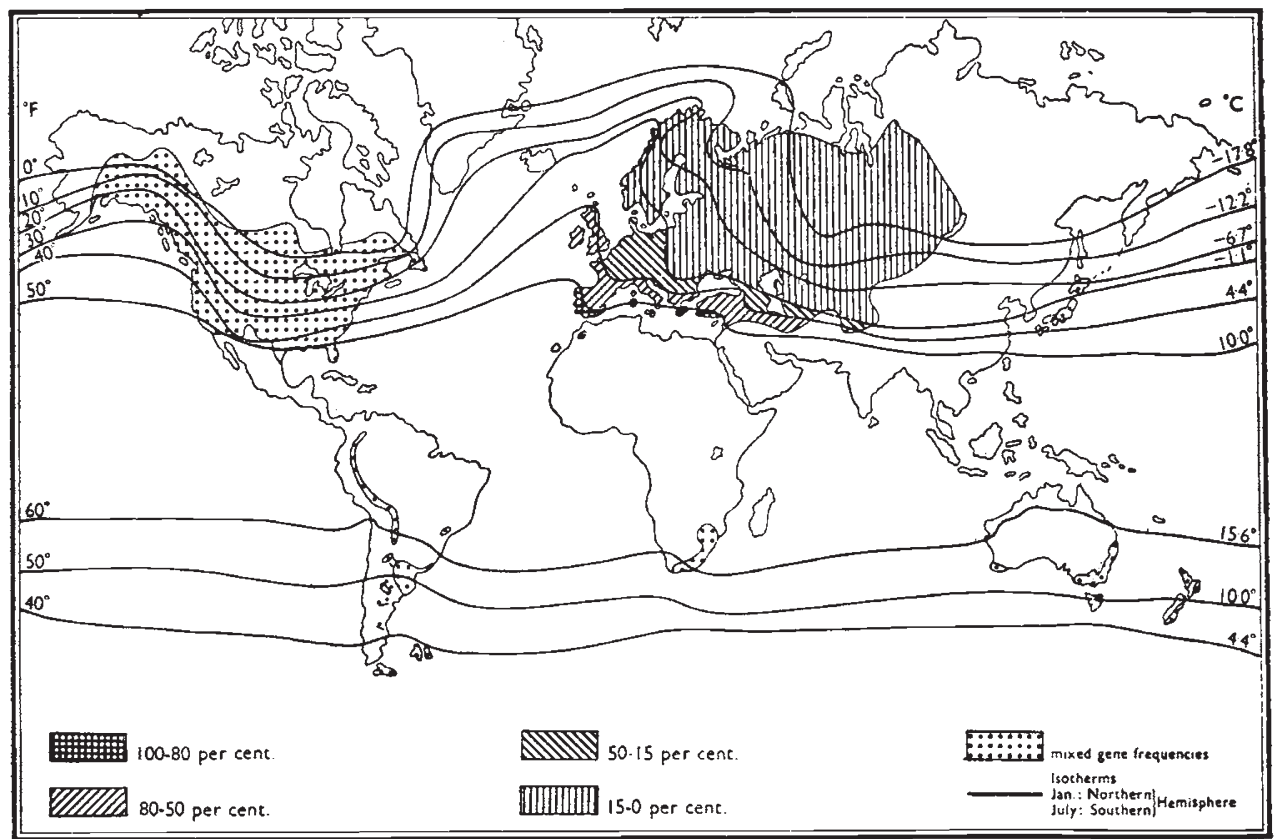

Fig. 4.-Distribution of linamarase gene frequencies in world populations of Trifolium repens $\mathrm{L}$. 


\section{DISCUSSION}

Huxley (1955) has emphasised the evolutionary significance of intraspecific differentiation. He stated that genic differences between populations may enable the species to occupy areas which environmentally are sharply distinct. If there is adaptation to a continuous range of environments, the formation of a ratio-cline will be apparent where a balanced equilibrium exists between the adaptive morphism

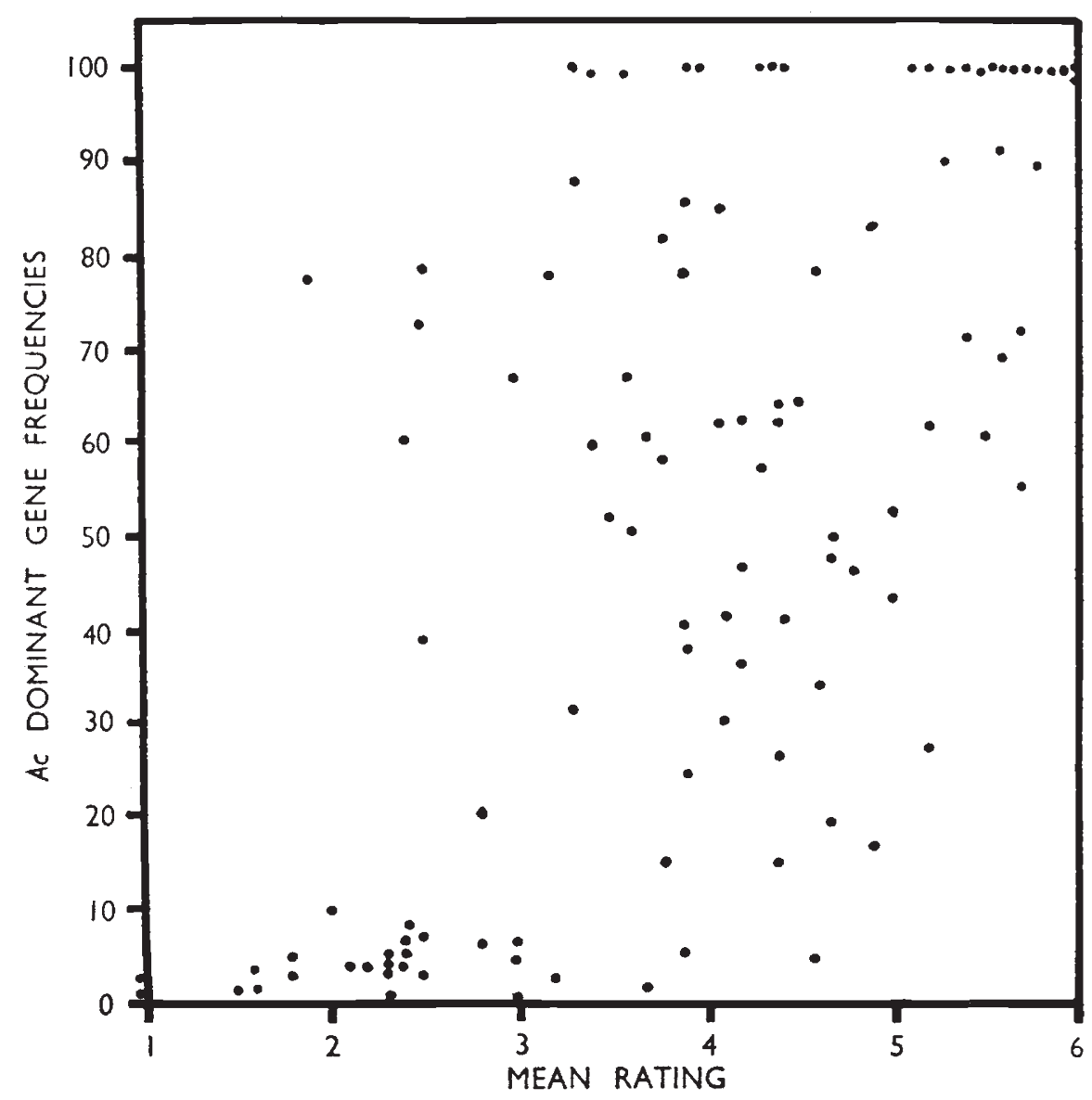

FIG. 5.-Correlation between lotaustralin $(A c)$ gene frequencies and mean rating of produced lotaustralin in world populations of $\mathcal{T}$. repens.

and the environment. The investigation of ratio-clines may lead to the exploration of selective forces. A typical example of a ratiocline has been demonstrated in $T$. repens. The dominant lotaustralin and linamarase gene frequencies decrease from roo to o per cent. as the mean winter temperature decreases. Therefore, winter temperature is considered as the major selective force in this example. It can also be seen that the gene frequency cline is more evident in those regions where the coldest month of the year has a temperature range below $40^{\circ} \mathrm{F}$. This range of required winter temperature can 
be found in the northern hemisphere but not in the southern hemisphere with the exception of such cold winter mountainous regions as Mt. Kosciusko.

The occurrence and spread of a mutant gene can influence considerably the selective advantage or disadvantage of a population, as is well illustrated in Pisum arvense L. (Scheibe, 1955). A pair of genes governs the presence or absence of a waxy layer on the leaves of $P$. arvense. A thick layer of wax is found on plants of dry climatic regions such as Asia Minor and the European Continent while populations have been found in the British Isles with thin waxy layers. Scheibe studied the behaviour of genotypes differing only in the waxy character under competition in a low rainfall area in Germany where a mixture consisting of 50 per cent. of each genotype was grown for four years. The waxy genotype increased to a frequency of $80 \cdot 9$ per cent. while the non-waxy genotype was reduced to $19 \cdot 1$ per cent. of the original population. The non-waxy phenotype was associated with a higher rate of transpiration which in turn reduced seed number and seed weight. This example shows that single gene mutants can contribute considerably to the selective potential of a species.

The distribution of allelic frequencies in populations according to selection pressure is well demonstrated in Ricinus communis L. and species of Eucalyptus. A single dominant allele $B$ produces waxy bloom on the stem of $R$. communis (Harland, 1947). The survey of $B$ gene frequencies in populations of Peru shows a gradual increase in the dominant allele with altitude. Plants carrying the $B$ gene failed to fruit except when growing in dry sunny conditions, but the $b b$ genotype showed normal fruiting under coastal, foggy conditions during the winter. This ratio-cline clearly indicates that the $B$ gene or some closely linked genes have some physiological disadvantage under humid conditions. Similar clinal variation was disclosed in Eucalyptus gigantea, $E$. gunnii and $E$. coccifera by Barber (1955). The appearance of glaucous stems and leaves shows a considerable clinal variation in Eucalyptus along a mountain transect from Golden Valley at I 200 feet to Great Lake at 3500 feet in Central North Tasmania. Within a species, the non-glaucous type is most common at low elevations, while increased glaucousness frequencies are found at higher elevation. According to Barber, the abundance of glaucous trees is correlated with changes in frost activity.

If one of the alleles becomes disadvantageous in a population, natural selection will rapidly reduce its frequency. This rapidity of natural selection is well illustrated in moths (Lepidoptera) (Ford, 1955). The dominant melanic allele of the moth has rarely been found in moth species of non-industrial areas. However, a number of species have become fully, and other species considerably, darker melanics during the last 100 years in the industrial areas of Great Britain and Western Europe. The influence of natural selection is 
also indicated in $T$. repens populations of North America and Japan. The introduced $T$. repens is slowly adapting to these new environments by forming gene frequency clines. Comparison can be made between the gene frequency clines of indigenous (European, Near Eastern) and introduced (North American) T. repens populations through their regression lines (fig. 6). The increase of gene frequencies per $\mathrm{I}^{\circ} \mathrm{F}$. of January mean temperature is 4.23 per cent. for $A c$ and 3. I 5 per cent. for $L i$ in indigenous populations, while the value for $A c$ falls to 0.68 per cent. in North American populations. In the European and Asiatic (mainland) regions, which are the oldest distribution areas, it can be considered that there is a balanced equilibrium

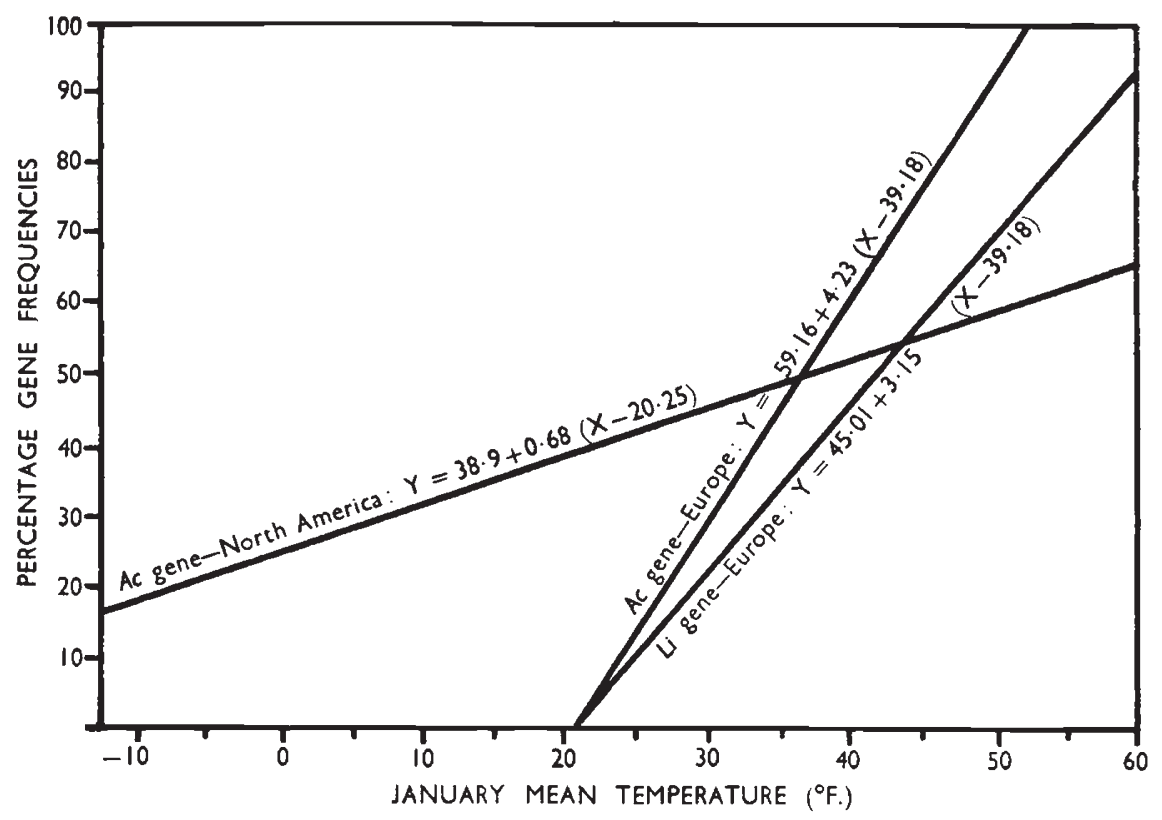

F1G. 6.-Comparison between the regression lines of gene frequencies in European and North American wild populations of $T$. repens $\mathrm{L}$.

between gene frequencies and January mean temperature. On the other hand, gene frequencies and January mean temperature have not yet reached an equilibrium in the North American population. It is postulated that the American gene cline is gradually moving under selection pressure and its regression line will occupy the same position as the European regression line when equilibrium is reached during the course of evolution. The postulate that natural selection is acting to form gene frequency clines in $T$. repens populations in North America has also been supported by the evidence of Portz and Jackobs (1955). Four thousand four hundred and fourteen plants of $T$. repens cultivated Ladino, have been tested from a geographical range between Washington and California. The frequencies of plants containing lotaustralin varied from 67 to o per cent. between seed lots of certified Ladino strains. A typical cline from south to north 
(high-low lotaustralin plant frequencies) has been disclosed. The original Ladino strain was found to contain $5 \cdot 2 \pm \mathrm{r} \cdot 95$ per cent. lotaustralin genes (Daday, I954c) and this increase is partly due to natural selection in U.S.A.

In spite of the fact that several single gene controlled enzymes are known in micro-organisms, no single gene controlled enzyme has been reported in flowering plants other than linamarase in T. repens. Six different quantities of enzyme production have been indicated (Daday, $1954 b$ ). It is still unknown whether the different quantities of linamarase are controlled by a series of alleles or by modifying genes.

The presence together of the products of the genes $A c$ and $L i$ determine the in vitro production of HCN; but, as suggested to the author by his colleague $\operatorname{Dr}$ F. H. W. Morley, it cannot be assumed that it is the product of this chemical reaction which is recognised by the forces of natural selection. The presence of several populations in which $A c$ is at low frequency and $L i$ at high frequency and vice versa (e.g. in North America, Fairbanks : $A c 4 \cdot 2, L i 38.6$ per cent. ; Brandon : $A c$ 29.3, $L i$ 8I. I per cent. ; and also the fact that in Europe $A c$ and $L i$ regression coefficients are significantly different, ${ }^{t}(86)=$ $\left.2 \cdot 206, \mathrm{P}=0 \cdot 05^{-0} \cdot 02\right)$ suggests that selection acts on these genes or their products independently. The presence of frequency clines in the European populations (Daday, 1954a) indicates that both genes are subject to agents of selection associated with temperature, but in the absence of further information, nothing more may be deduced.

These findings underline an important principle. Although the particular action of a gene product may be known, it is not necessarily this action which is the subject of selection under natural conditions.

The old naturalists (e.g. Kerner et al., 1894) emphasised the protective function of alkaloids and other substances in flowering plants. The presence of lotaustralin in T. repens may afford protection against the feeding of such animal predators as rabbits and snails, but probably the major role is exerted through a physiological process as yet not understood.

The present investigation has shown that $T$. repens has formed a balanced gene frequency cline in its indigenous distribution areas, and that natural selection is still acting to establish equilibrated gene frequency clines in the areas of introduced populations wherever the selective force, low winter temperature range, exists.

\section{SUMMARY}

I. The distributions of lotaustralin $(A c)$ and linamarase $(L i)$ gene frequencies in wild populations of $\mathcal{T}$. repens are presented.

2. Gene distribution :

(a) In Europe, North Africa and the mainland of Asia, there are Ioo to o per cent. gene frequency clines. 
(b) In North America and Japan, decreases in $A c$ gene frequencies exist from South to North.

(c) In South America, South Africa, Australia and New Zealand, gene frequencies exhibit an irregular pattern.

3. The decreasing gene frequencies were found to be highly correlated with decrease in mean winter temperature.

4. There is a relationship between gene frequency and quantity of gene products.

5. It is apparent that natural selection has already produced a balanced equilibrium in Europe and the mainland of Asia, and that natural selection is still in progress in North America and Japan.

6. Formation of $\mathrm{Ac}, \mathrm{Li}$ gene frequency clines are not expected in the southern hemisphere with the exception of mountainous regions.

Acknowledgments.-I am greatly indebted to Professors T. J. Jenkin and E. T. Jones, the former and present Directors of the Welsh Plant Breeding Station for facilities to carry out the investigation. It is a pleasure to acknowledge the helpfulness of Mr A. G. G. Hill, Director of the Commonwealth Bureau of Pastures and Field Crops, and the British Council, in organising the seed collections from many parts of the world. The author also wishes to thank Professor Ing. Agr. Arturo Burkart for the South American distribution map of T. repens and useful information, Drs E. A. Hollowell, U.S.A., W. G. Dore, Canada, B. E. Codd, S. Africa, D. K. Kakara, Japan, G. L. da Rocha, J. R. de Otero, Brazil, Mr D. P. Bignoli, Argentina, Staff of Grassland Division, New Zealand and Professor C. M. Donald, Australia, for their seed samples and distribution maps. I am also indebted to Mr G. A. McIntyre for the statistical analyses, Mr W. Hartley, C.S.I.R.O., Canberra, for suggestion in manuscript, Professor P. T. Thomas, University College of Wales, Mr W. E. Davies, the head of the Clover Breeding Section of the Welsh Plant Breeding Station for their interest and advice in the work; and W. Y. Krygier for technical help.

\section{REFERENCES}

ATwood, s. S., AND sullivan, J. T. 1943. Inheritance of a cyanogenetic glucoside and its hydrolysing enzyme in Trifolium repens. F. Hered., 34, 311-320.

BARBER, H. N. 1955. Adaptive gene substitutions in Tasmanian Eucalypts: I. Genes controlling the development of glaucousness. Evolution, 9, 1-14.

C.s.r.R. 1933. Meteorological data for certain Australian localities. C.S.I.R. pamphlet No. 42.

Clayton, н. н. 1927. World Weather Records. The Lord Baltimore Press, Baltimore. Coop, I. E. 1940. Cyanogenesis in white clover (Trifolium repens L.). III. A study of linamarase, the enzyme which hydrolyses lotaustralin. N.Z. F. Sci. Tech., 22, 7 I B-83 B.

CORKILL L. 1940. Cyanogenesis in white clover (Trifolium repens L.). I. Cyano. genesis in single plants. N.Z. F. Sci. Tech., $22,6{ }_{5} \mathrm{~B}-67 \mathrm{~B}$.

CORKIr.L, L. 1942. Cyanogenesis in white clover (Trifolium repens L.). V. The inheritance of cyanogenesis. N.Z. F. Sci. Tech., 23, 1 78B-193B.

CORKILL, L. 1952. Cyanogenesis in white clover (Trifolium repens L.). VI. Experiments with high-glucoside and glucoside-free strains. N.Z. F. Sci. Tech., 34, I A- I6A.

DADAY, H. 1954a. Gene frequencies in wild populations of Trifolium repens. I. Distribution by latitude. Heredity, $8,6 \mathrm{I}-78$.

DADAY, H. I $954 b$. Gene frequencies in wild populations of Trifolium repens. II. Distribution by altitude. Heredity, $8,377-384$. 
DADAY, H. I954c. Gene frequencies in strains of Trifolium repens L. Nature, 174, $52 \mathrm{I}$. Dobzhansky, тh. 195I. Genetics and the Origin of Species. Columbia Press, New York.

FORD, E. B. I 955 . Moths. Collins, London.

HARLAND, s. c. 1947. An alteration in gene-frequency in Ricinus communis L. due to climatic conditions. Heredity, I, I 2 I-I 25 .

HUXLEY, J. I955. Morphism and evolution. Heredity, 9, I-52.

KERNer, A., VON MARILAUn AND Oliver, F. W. I894. The Natural History of Plants. Blackie, London.

komarov, v. L. 1945. Flora U.R.S.S. Editio Academiae Scientiarum U.R.S.S., Moscow. MELVILle, F., AND DOAK, B. W. I940. Cyanogenesis in white clover (Trifolium repens L.). II. Isolation of the glucosidal constituents. N.Z. J. Sci. Tech., $22,67 \mathrm{~B}-7 \mathrm{IB}$.

PORTZ, H. L., AND JACKoBs, J. A. 1955. Differences between seed lots of Ladino clover in cyanophoric properties. Agron. 7., 47, 143-145.

scheibe, A. 1955. Die Wirkung der natürlichen Auslese bei Pisum arvense. Formen mit und ohne Wachsschicht. Züchter, 25, 97-103.

VAVILOV, N. I. I95I. The origin, variation, immunity and breeding of cultivated plants. Chronica Botanica, 13, No. I/6. 
APPENDIX I

Phenotypes and gene frequencies in wild populations of Trifolium repens

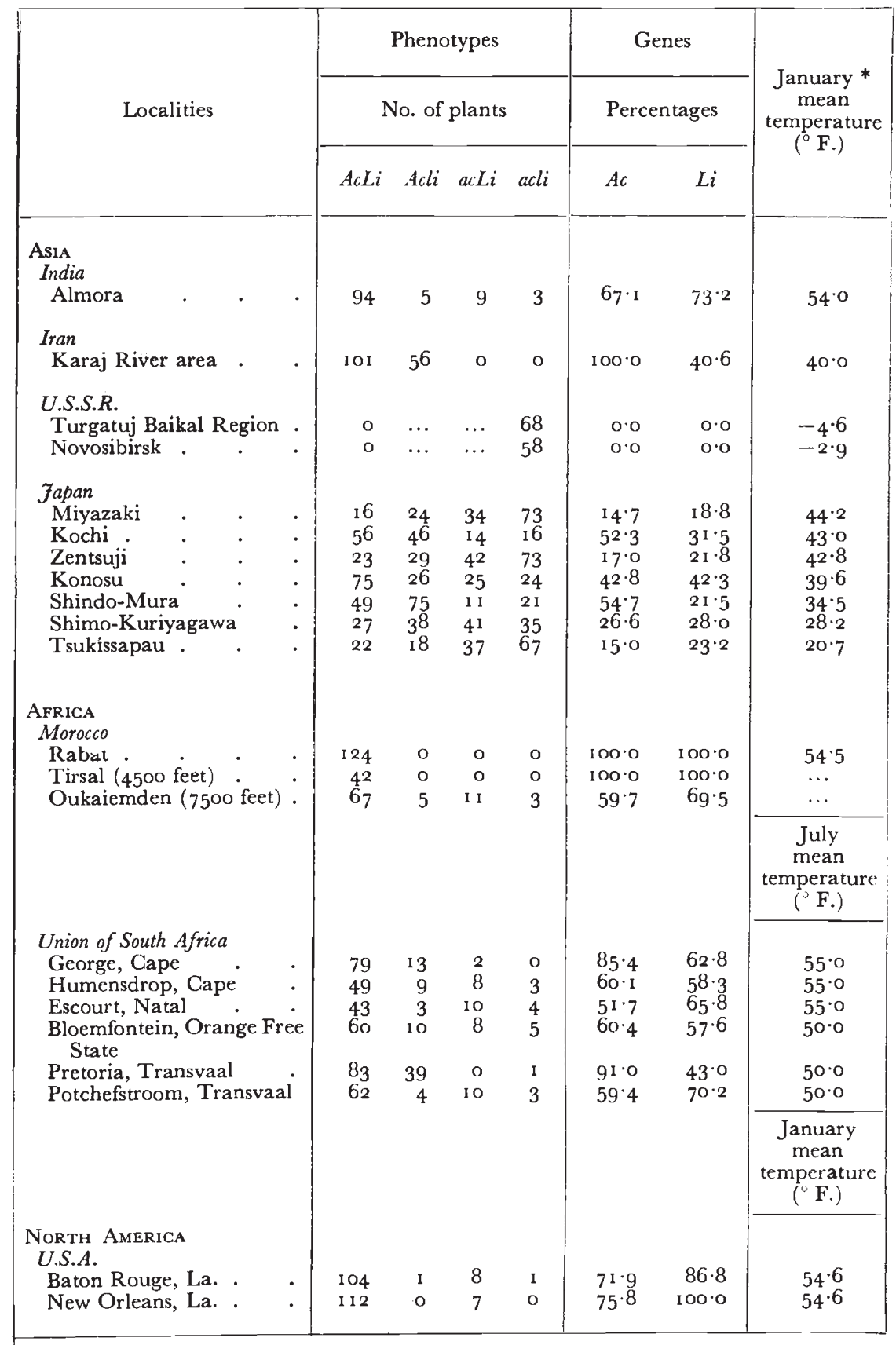

* Data obtained from individual meteorological stations and also from C.S.I.R. (1933), Clayton (1927). 
APPENDIX 1 -continued

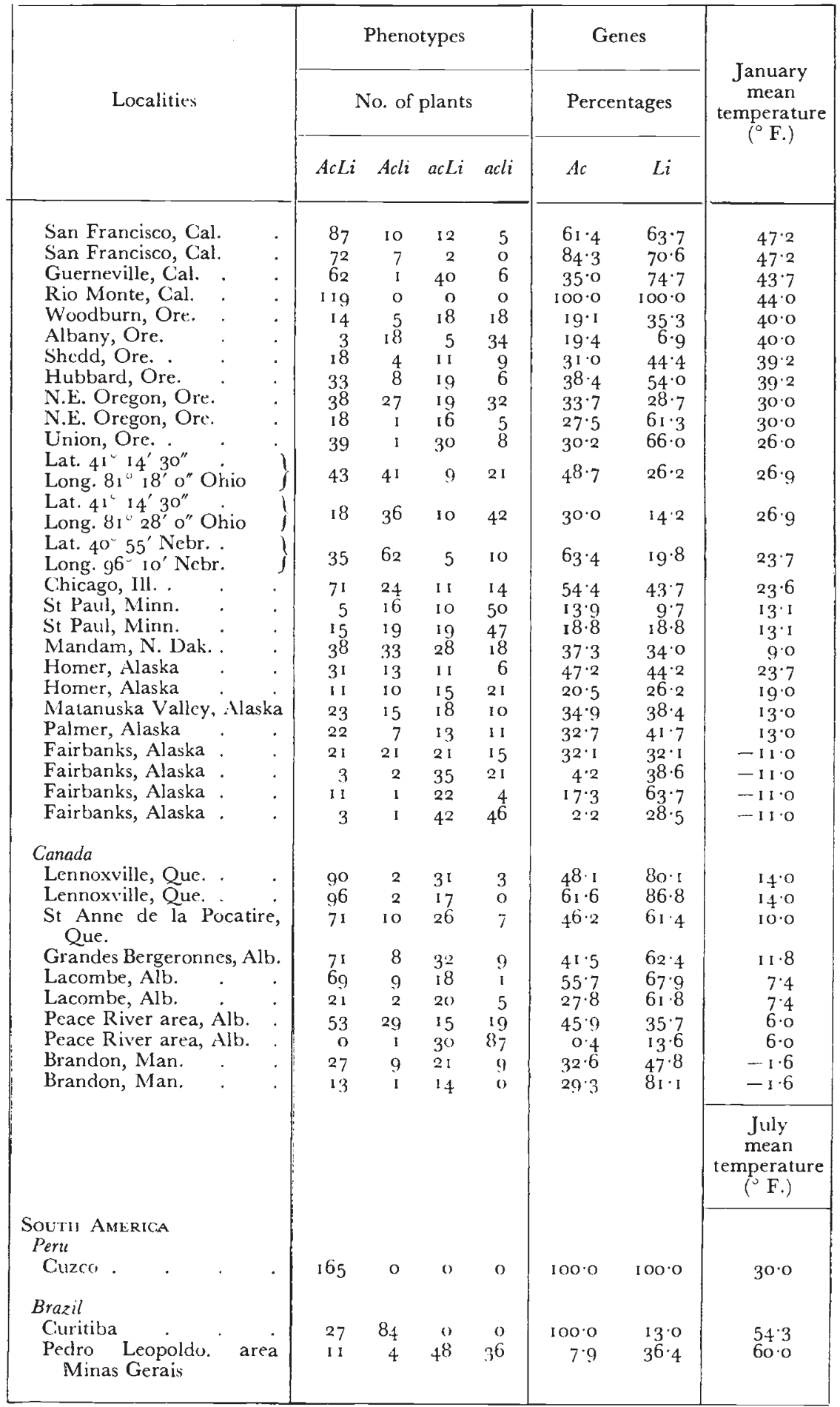


APPENDIX I-continued

\begin{tabular}{|c|c|c|c|c|c|c|c|}
\hline \multirow{3}{*}{ Localities } & \multicolumn{4}{|c|}{ Phenotypes } & \multicolumn{2}{|c|}{ Genes } & \multirow{3}{*}{$\begin{array}{c}\text { July } \\
\text { mean } \\
\text { temperature } \\
\left({ }^{\circ} \mathrm{F} .\right)\end{array}$} \\
\hline & \multicolumn{4}{|c|}{ No. of plants } & \multicolumn{2}{|c|}{ Percentages } & \\
\hline & AcLi & Acli & acLi & acli & Ac & $L i$ & \\
\hline \multicolumn{8}{|l|}{ Argentina } \\
\hline Monte, Prov. Buenos Aires & 76 & 7 & 17 & 4 & $55 \cdot 1$ & $67 \cdot 5$ & $4^{8 \cdot 9}$ \\
\hline Las Rosas, Prov. Santa Fe & 122 & 12 & 13 & 7 & $64 \cdot 0$ & $64 \cdot 9$ & $50 \cdot 8$ \\
\hline Esquel, Gov. of Chubut & 46 & 45 & 7 & 7 & 63.5 & $29 \cdot 6$ & $30 \cdot 0$ \\
\hline $\begin{array}{l}\text { Sarmiento, Gov. } \\
\text { Comorodo Rivadavia }\end{array}$ & $2 \mathrm{I}$ & 28 & 30 & $6 i$ & 19.4 & $20 \cdot 3$ & $37 \cdot 8$ \\
\hline \multicolumn{8}{|l|}{ Australia } \\
\hline Bateman's Bay, N.S.W. & 6 & 2 & $7^{2}$ & 23 & $4 \cdot 0$ & $50 \cdot 7$ & $53 \cdot 0$ \\
\hline Bodalla, N.S.W. & 78 & 3 & 14 & 3 & $5^{8 \cdot 4}$ & $75 \cdot 3$ & $5^{1} \cdot 9$ \\
\hline Central Tilba, N.S.W. & I & o & 78 & 22 & 0.5 & 53.3 & $5^{1 \cdot 9}$ \\
\hline Central 'Tilba, N.S.W. & I & o & $8_{4}$ & 4 & 0.6 & $78 \cdot 8$ & $5^{1 \cdot 9}$ \\
\hline Borogo, N.S.W. & 59 & 4 & 24 & 16 & $37 \cdot 7$ & 559 & $48 \cdot 7$ \\
\hline Bega, N.S.W. & 37 & 7 & 21 & 2 & $4^{1} \cdot 4$ & 634 & $48 \cdot 7$ \\
\hline Bega, N.S.W. & 0 & 0 & 29 & 44 & $0 \cdot 0$ & $22 \cdot 4$ & $48 \cdot 7$ \\
\hline Bega, N.S.W. & 10 & o & 76 & 21 & $4 \cdot 8$ & $55 \cdot 7$ & $48 \cdot 7$ \\
\hline Tathra, N.S.W. & I 2 & 0 & 44 & $5^{1}$ & $5 \cdot 8$ & $3 \mathrm{I} \cdot \mathrm{O}$ & $48 \cdot 7$ \\
\hline Nimmitabel, N.S.W. & 0 & 1 & 37 & 35 & 0.7 & $29 \cdot 8$ & $3^{6 \cdot 7}$ \\
\hline Butiers, N.S.W. & 7 & o & $5 \mathrm{I}$ & 44 & 3.5 & $43 \cdot 3$ & $\ldots$ \\
\hline Big-Bog, N.S.W. & 8 & 2 & 60 & 35 & 4.9 & $40 \cdot 6$ & 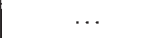 \\
\hline Melbourne, Vic. . & 6I & 8 & I5 & $6 \mathrm{I}$ & $27 \cdot 6$ & $3^{1 \cdot 0}$ & $50 \cdot 3$ \\
\hline Somers, Vic. . . & Ig & 9 & II & 7 & $37 \cdot 4$ & $4 \mathrm{I} \cdot \mathrm{O}$ & $48 \cdot 8$ \\
\hline Pomborneit, Vic. . & 8 & 12 & 6 & $9^{2}$ & $8 \cdot 9$ & $6 \cdot I$ & $50 \cdot 0$ \\
\hline Mt. Gambier, S.A. & 44 & 9 & 36 & 33 & 24.8 & $4 \mathrm{r} \cdot 3$ & $49 \cdot 1$ \\
\hline Mt. Gambier, S.A. & 16 & 22 & 20 & $5^{6}$ & $18 \cdot 3$ & I7:3 & $49 \cdot 1$ \\
\hline Hd. Benara, S.A. . & 99 & 7 & 5 & 2 & $75 \cdot \mathrm{I}$ & $7 \mathrm{~T} \cdot 8$ & \\
\hline Hobart, Tas. & 84 & 6 & 5 & 3 & $7 \mathrm{I} \cdot 4$ & $69 \cdot 7$ & $46 \cdot 6$ \\
\hline Ranelagh, Tas. & 85 & I & 30 & 7 & $45 \cdot \mathrm{I}$ & $74 \cdot 5$ & $43 \cdot 0$ \\
\hline \multicolumn{8}{|l|}{ Mt. Kosciusko Region } \\
\hline Maffra, 3000 feet & 4 & 2 & 43 & 47 & $3 \cdot 2$ & $28 \cdot 6$ & $\ldots$ \\
\hline Jindabyne, 3000 feet & 7 & 6 & 84 & 39 & $4 \cdot 9$ & $42 \cdot 5$ & \\
\hline Hotel Kosciusko, 5200 feet & 8 & I & 78 & 30 & $3 \cdot 9$ & $48 \cdot 5$ & $31 \cdot 9$ \\
\hline Munyang, 4600 feet & 6 & 2 & $9^{2}$ & $4^{2}$ & $2 \cdot 9$ & $44 \cdot 3$ & $\cdots$ \\
\hline $\begin{array}{l}\text { The Smiggin Holes, } 5500 \\
\text { feet }\end{array}$ & 12 & 2 & 84 & 28 & $5 \cdot 7$ & $5^{1 \cdot 2}$ & $\ldots$ \\
\hline Spencer's Creek, 5700 feet & 2 & 4 & 20 & 12 & $8 \cdot 2$ & $35 \cdot \mathrm{I}$ & \\
\hline The Chalet, $5^{800}$ feet & I I & 5 & 84 & 53 & $5 \cdot 4$ & $38 \cdot 4$ & $26 \cdot 5$ \\
\hline \multicolumn{8}{|l|}{ Mt. Gingera } \\
\hline $\begin{array}{l}\text { Mt. Gingera, A.C.T., } 5973 \\
\text { feet }\end{array}$ & 0 & 0 & $8_{3}$ & 2 & $0 \cdot 0$ & $84 \cdot 7$ & $\ldots$ \\
\hline $\begin{array}{l}\text { Mt. Gingera, A.C.T., } 5973 \\
\text { feet }\end{array}$ & 2 & $\mathrm{o}$ & I 6 & 39 & I 8 & $17 \cdot 3$ & $\cdots$ \\
\hline \multicolumn{8}{|l|}{ New Zealand } \\
\hline Winston & 70 & 4 & $4^{I}$ & 7 & $37 \cdot 3$ & $70 \cdot 0$ & $+8 \cdot 8$ \\
\hline Hastings & 68 & I & 0 & o & $100 \cdot 0$ & $88 \cdot 0$ & $5.5 \cdot 1$ \\
\hline Nelson . & 44 & 3 & 3 & 3 & $66 \cdot 4$ & $66 \cdot 4$ & $54 \cdot 2$ \\
\hline Palmerston North . & 30 & I & 7 & 4 & $48 \cdot 8$ & 65.5 & $53 \cdot 1$ \\
\hline
\end{tabular}

